Sarab Osborn's World 


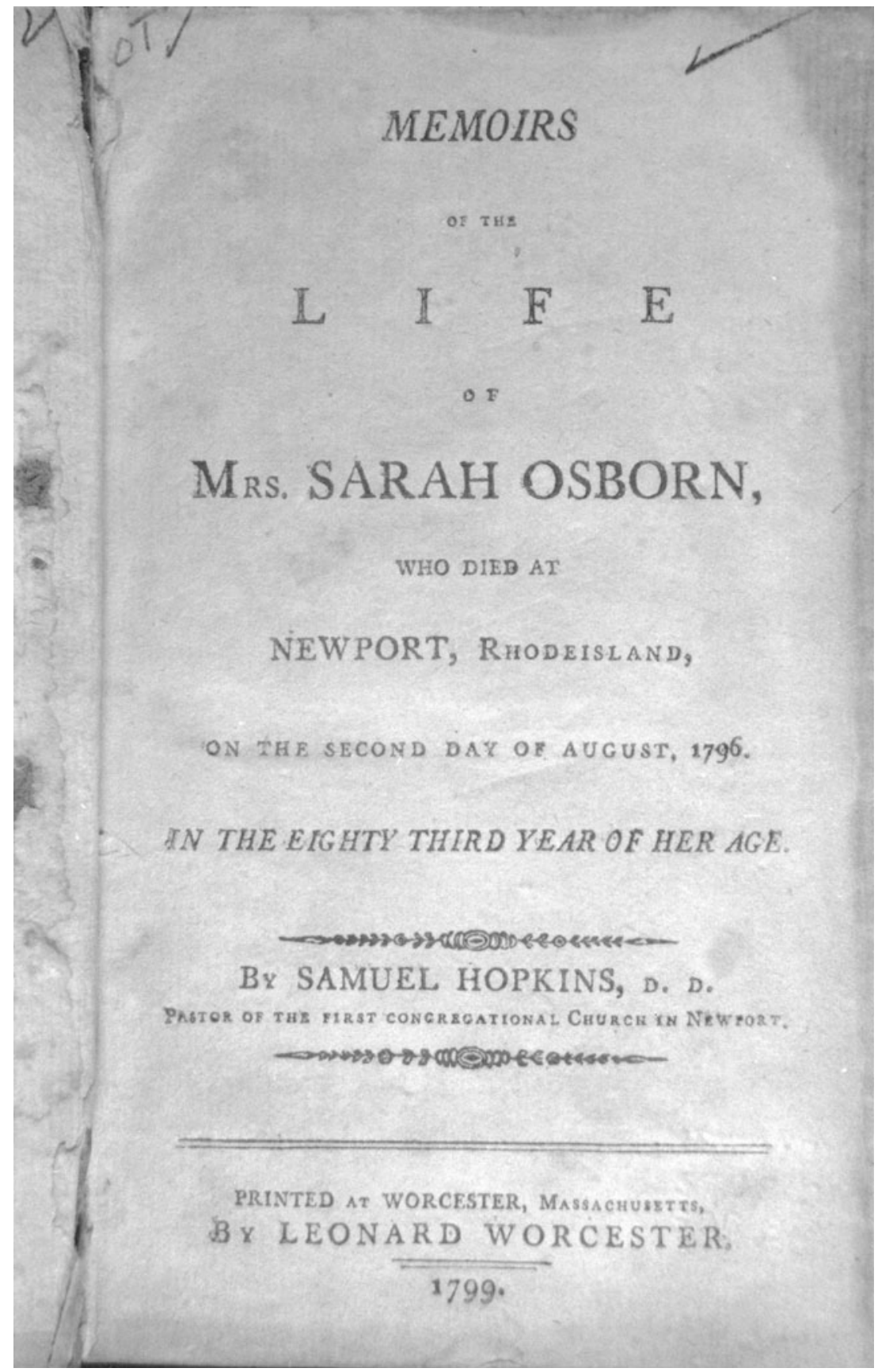

Title page of Samuel Hopkins, Memoirs of the Life of Mrs. Sarah Osborn (Worcester, Mass.: Leonard Worcester, 1799). Photograph courtesy of the Newport Historical Society. 


\title{
Sarab Osborn's World
}

The Rise of Evangelical Christianity in Early America

Catherine A. Brekus

\author{
Yale \\ UNIVERSITY \\ PRESS
}




\section{NEW DIRECTIONS IN NARRATIVE HISTORY}

John Demos and Aaron Sachs, Series Editors

The New Directions in Narrative History series includes original works of creative nonfiction across the many fields of history and related disciplines. Based on new research, the books in this series offer significant scholarly contributions while also embracing stylistic innovation as well as the classic techniques of storytelling. The works of the New Directions in Narrative History series, intended for the broadest general readership, speak to deeply human concerns about the past, present, and future of our world and its people.

Published with assistance from the foundation established in memory of Philip Hamilton McMillan of the Class of r894, Yale College, and from the Annie Burr Lewis Fund.

\section{Copyright (C) 2013 by Catherine A. Brekus.}

All rights reserved.

This book may not be reproduced, in whole or in part, including illustrations, in any form (beyond that copying permitted by Sections Io7 and Io8 of the U.S. Copyright Law and except by reviewers for the public press), without written permission from the publishers.

Yale University Press books may be purchased in quantity for educational, business, or promotional use. For information, please e-mail sales.press@yale.edu (U.S. office) or sales@yaleup.co.uk (U.K. office).

Designed by Mary Valencia.

Set in Adobe Caslon type by Newgen North America. Printed in the United States of America.

Library of Congress Cataloging-in-Publication Data

Brekus, Catherine A.

Sarah Osborn's world : the rise of evangelical Christianity in early

America / Catherine A. Brekus.

p. cm. - (New directions in narrative history)

Includes bibliographical references and index. ISBN 978-0-300-I8290-3 (alk. paper)

I. Osborn, Sarah, 1714-1796. 2. Christian biography-

United States. I. Title.

$$
\begin{aligned}
& \text { BRI725.07B } 742013 \\
& 277.3^{\prime} 07092-\mathrm{dc} 23
\end{aligned}
$$

2012019515

A catalogue record for this book is available from the British Library.

This paper meets the requirements of ANSI/NISO Z39.48-1992 (Permanence of Paper). 
publication of this book is enabled by a grant from

Jerwish Federation of Greater Hartford 
For my mother, Trudy Brennan Brekus

And in memory of my father, Gordon L. Brekus (I930-20II)

Remembering speechlessly we seek the great forgotten language, the lost lane-end into heaven, a stone, a leaf, an unfound door.

- Thomas Wolfe, Look Homeward Angel 
Write this for a memorial in a book.

—Exodus I7:I4 
This page intentionally left blank 